\title{
Regarding Microbiological Control of Cellular Products: The Relevance of the Cellular Matrix, Incubation Temperature, and Atmosphere for the Detection Performance of Automated Culture Systems [Transfus Med Hemother. 2020;47:254-63]
}

\author{
Rainer Moog \\ DRK Blutspendedienst Nord-Ost gGmbH, Institut Cottbus, Cottbus, Germany
}

\section{Dear Editor,}

Günther et al. [1] evaluated the method suitability and possible effects of the cell matrix, incubation temperature, and oxygen pressure on the detection performance of the automated BacT/ALERT dual temperature system. Fractionated peripheral leukocytes from healthy human donors were spiked with microbial strains recommended by the European Pharmacopeia. Aerobic and anaerobic incubation was performed using iAST and iNST culture bottles at two different temperatures as recommended by the Paul-Ehrlich-Institute (PEI) for stem cell products [2].

The use of donor buffy coats (BCs) for validation as surrogates of stem cell matrix is suggested in PEI's notification. However, we noticed that autologous patient stem cells showed different validation results with respect to used culture bottles than BCs [3]. While all spiked microbes were safely detected in iAST/iNST culture bottles according to their growth behavior in the $\mathrm{BC}$ matrix, the detection of microbes differed significantly using standard iAST/iNST and iFA/iFN bottles with resorbing polymers. By using aerobic iFA Plus and anaerobic iFN Plus culture bottles incubated at different temperatures all spiked microbes were detected in autologous stem cell products. Patients are often under antibiotic treatment resulting in growth inhibition of killing of germs with a false-negative result. Therefore, the choice of the right in-

karger@karger.com www.karger.com/tmh

Karger ${ }^{\prime}=$

GOPEN ACCESS
(C) 2021 The Author(s)

Published by S. Karger AG, Basel

This is an Open Access article licensed under the Creative Common Attribution-NonCommercial-4.0 International License (CC BY-NC) (http://www.karger.com/Services/OpenAccessLicense), applicable to the online version of the article only. Usage and distribution for commercial purposes requires written permission. cubation bottle is of utmost importance in microbial testing of stem cell products. Even the relatively slow-growing bacterium Propionibacterium acnes, which can cause severe cases of folliculitis, prosthetic valve endocarditis as well as systemic infections of the critically ill patient, showed positive signals in IFA Plus culture bottles [4]. By using iFA Plus and iFN Plus culture bottles with neutralizing polymers, which remove antibiotics, we were able to safely detect all spiked microbes in autologous stem cell products.

Furthermore, we wish to point out that a $\mathrm{BC}$ with an adjusted final concentration of $2 \times 10^{6} \mathrm{cells} / \mathrm{mL}$ is not identical to the various product characteristics of stem cells due to individual mobilization of the donor. The number of CD34+ is higher in stem cell products than in non-mobilized $\mathrm{BC}$ and the volume of a stem cell product is larger because BCs are collected from whole blood. Further differences are observed for hematocrit, platelet count and product volume. Although we follow PEI's proposal that $\mathrm{BC}$ can be used as surrogate in validation studies for ethical reasons, we feel that product differences should be considered when drawing conclusions.

\section{Disclosure Statement}

The author declares no conflict of interest. 


\section{References}

1 Günther SK, Geiss C, Kaiser SJ, Mutters NT, Günther F. Microbiological control of cellular products: the relevance of the cellular matrix, incubation temperature, and atmosphere for the detection performance of automated culture systems. Transfus Med Hemother. 2020 Jun;47(3):254-63.

2 Paul-Ehrlich-Institut-Microbial Safety. Stellungnahme zur mikrobiologischen Sicherheit von hämatopoetischen Stammzellpräparaten. 2014. Available from:http://www.pei.de/ SharedDocs/Downloads/blut/stammzellengenehmigung-21a-amg/pei-stellungnahmemikrobiologischekontrolle-stammzellen.pdf. 3 Arlt N, Rothe R, Sielaff S, Juretzek T, Peltroche H, Moog R. Sterility release testing of peripheral blood stem cells for transplantation: impact of culture bottles and incubation tem- perature. Transfusion. 2018 Dec;58(12): 2918-23.

4 Arlt N, Rothe R, Juretzek T, Peltroche $\mathrm{H}$, Tonn T, Moog R. Detection of the relatively slow-growing Propionibacterium acnes in seven matrices of blood components and advanced therapeutical medicinal products. Transfus Apheresis Sci. 2017 Jun;56(3): 461-5. 